\title{
Li Chinese
}

National Cancer Institute

\section{Source}

National Cancer Institute. Li Chinese. NCI Thesaurus. Code C158174.

A Chinese person from the Li ethnic group. 